\title{
Training to Be an Early Childhood Professional: Teacher Candidates' Perceptions about Their Education and Training
}

\author{
Carmen Sherry Brown ${ }^{1}$, Tracy N Cheddie ${ }^{1}$, Lynell F Horry ${ }^{1}$, Julia E Monk ${ }^{1}$ \\ ${ }^{1}$ Hunter College, City University of New York (CUNY), USA \\ Correspondence: Carmen Sherry Brown, Hunter College, City University of New York (CUNY), USA.
}

Received: March 28, 2017

doi:10.11114/jets.v5i6.2308

\author{
Accepted: May 1, $2017 \quad$ Online Published: May 11, 2017 \\ URL: https://doi.org/10.11114/jets.v5i6.2308
}

\begin{abstract}
Professionalism in the context of early care and education has received considerable attention in recent years (Caulfield, 1997; Harte, 2011; Tigistu, 2013). According to the 2010 National Association for the Education of Young Children (NAEYC) Standards for Initial \& Advanced Early Childhood Professional Preparation Programs, teacher candidates prepared in early childhood degree programs should identify and conduct themselves as members of the profession, know and use ethical guidelines and utilize other professional standards related to early childhood practice (NAEYC, 2012). In their final journal entry for a student teaching practicum course, teacher candidates in an accredited early childhood program reflected on what it means to be an early childhood professional. In alignment with the 2010 NAEYC Standards, teacher candidates appeared to recognize that being an early childhood professional means having an understanding of the specialized knowledge required to be effective in early childhood education. They also appeared to be aware that providing responsive, supportive curricula, which acknowledges and respects the whole child and family and their cultural backgrounds, is an integral aspect of the early childhood profession. Implications from this inquiry suggest that the early childhood program should ensure the fidelity to the NAEYC Standards by aligning assignments that incorporate the language and expectations of the Standards.
\end{abstract}

Keywords: early childhood education, pre-service teachers, professionalism

\section{Introduction}

According to the Professional Standards Council (2015) a profession is a disciplined group of individuals who adhere to ethical standards. This group positions itself as possessing special knowledge and skills in a widely recognized body of learning derived from research, education and training at a high level and is recognized by the public as such. A professional is also prepared to apply this knowledge and exercise these skills in the interest of others.

A professional is a member of a profession. Professionals are governed by codes of ethics and profess commitment to competence, integrity and morality, altruism and the promotion of the public good within their expert domain. Professionals are accountable to those served and to society (PSC, 2015). Professionalism comprises the personally held beliefs about one's own conduct as a professional. Professionalism is typically defined as acting in accordance with agreed-upon professional standards or ethical codes (Castle, 2009). It is often linked to the upholding of the principles, laws, ethics and conventions of a profession as a way of practice (PSC, 2015).

Professionalism is a contemporary issue in education and more recently in early years education and care (Brock, 2006). Professionals in the field of early childhood education include individuals who provide direct services to young children (from birth through age 8) and their families, as well as those who administer the programs in which these individuals work (NAEYC, n.d.). Being a professional in this field encompasses the standards of education and training that prepare early childhood teacher candidates with the specific knowledge and skills necessary to perform the role of an early childhood educator. According to Caulfield (1997), being a professional in early childhood involves a shared set of skills that are used to improve the quality of caregiving practices and interactions between professional caregivers and the children and families that they work with. There are common aspects of professionalism that differentiate early childhood education from other fields (Caulfield, 1997). Educators in the field do not determine these aspects of professionalism, and therefore it is a challenge for early childhood educators to define their profession (Watts, 2009).

Although criteria exist that outline the aspects of being a professional in early childhood education (e.g., Division for Early Childhood code of ethics, 2009; NAEYC code of ethical conduct, 2005), the purpose of this qualitative study was 
to examine teacher candidates' perceptions about their preparation and readiness to become professionals in the field of early childhood education. To determine teacher candidates' views about their preparation to become early childhood professionals and to better understand their beliefs and attitudes with regards to their perceptions about their readiness to become professionals in the field, this study sought to answer the following research question: How do teacher candidates perceive their preparation to become professionals in the field of early childhood education?

\subsection{Professional Preparation}

With the heightened focus of the role early care and preschool play in the education of young children, early childhood professionals are being asked to have an in-depth understanding of child development and learning as well as provide rich, meaningful educational experiences for all children in their care (Sheridan, Edwards, Marvin, \& Knoche, 2009). The complexity of teaching preschool children requires the ability to be reflective, active and enthusiastic in providing a setting that is cognitively challenging, engaging and appropriate.

There is a correlation between high-quality programs and credentialed personnel (Bredekamp \& Goffin, 2012). In this light, teacher educators, policy makers and concerned citizens are working to ensure that all children have the early experiences necessary for optimal learning with highly trained early childhood educators.

The 2010 National Association for the Education of Young Children (NAEYC) Standards for Early Childhood Professional Preparation Programs (Standards) are used in graduate programs preparing candidates for leadership roles in the field as accomplished teachers, administrators, state early childhood specialists, child and family advocates, professional development specialists, teacher educators and researchers. There are seven core standards that describe what well-prepared teacher candidates should know and be able to do:

1. Promote child development and learning.

2. Build family and community relationships.

3. Observe, document and assess to support young children and families.

4. Use developmentally effective approaches to connect with children and families.

5. Use content knowledge to build meaningful curriculum.

6. Grow as a professional.

7. Participate in early childhood field experiences.

The NAEYC Standards represents a sustained vision for the early childhood field and more specifically for the programs that prepare the professionals working in the field (NAEYC, 2012). These standards express a national vision of excellence for early childhood professionals. The standards for early childhood teacher preparation are a roadmap towards teaching excellence and professionalism (Gordon \& Browne, 2015).

\section{Methods}

\subsection{Participants}

Twenty-seven teacher candidates, who were enrolled in an early childhood student teaching practicum in the spring of 2015, participated in this inquiry. All of the teacher candidates were completing coursework that would lead them to obtaining their Master's degree in early childhood education (Birth-Grade 2). All of the teacher candidates were part of a prekindergarten teacher preparation project. This project supported early childhood teacher candidates in obtaining their Master's degree and Birth-Grade 2 teacher certificate in 15 months while teaching in a large urban city prekindergarten classroom.

The fully funded rigorous program was competitive and the applicants had to meet minimum criteria to be considered for the program: Have a Bachelor's degree in liberal arts or a related field, have a minimum GPA of 3.0, and be available to begin the program in June 2014.

\subsection{Early Childhood Program}

The participants of this study attended an accredited school of education (SOE) that is located in a large urban area. The early childhood education program in the SOE introduces graduate teacher candidates to learning theories, concepts and strategies for children from birth through age 8 . The program offers a clinically rich experience designed to prepare teacher candidates to have a strong foundation in child development theory and research and developmentally appropriate methodology. The early childhood degree program prepares teacher candidates for teaching in a variety of diverse settings that encompass the early childhood years.

The early childhood program coursework supports teacher candidates in guiding the social-emotional, physical and cognitive development of young children. The program covers curriculum design and advanced teaching theories as 
well as the psychological, sociological and cultural development of children. The program includes curriculum planning, research and field experiences. The coursework in the early childhood program includes leadership and collaborative opportunities to further support teacher candidates in becoming leaders and advocates in the field.

\section{Course}

\subsection{Supervised Practicum in Early Childhood Education}

The supervised practicum in early childhood course has two key components: (1) 20 days of practicum in Pre-K, K, or grades 1-2 and (2) bi-weekly seminars (15 hours). The practicum builds on prior coursework and field experiences by providing guidance and reflective discussion that allow teacher candidates to enhance their teaching skills in early childhood education settings. Specific information regarding professional issues, ethical behaviors, and child advocacy are also provided and reviewed.

\section{Fieldwork experience}

Fieldwork experiences are designed to give the teacher candidate the opportunity to gain authentic insight into the curriculum and organization of the school and classroom environment (Dudiak, Dembroski, Kelly, \& McNair, 2015) and are a vital component in the early childhood teacher preparation program. Field experiences are well planned and sequenced, and allow teacher candidates to integrate theory, research and practice (NAEYC, 2012).

Fieldwork experiences in the early childhood program are paired with courses that will guide classroom observations, pedagogical development and teaching experience. Courses in the early childhood program that have identified fieldwork hours included in the syllabi require teacher candidates to observe and document children's development as well as the curricula and environment that supports this development.

Courses that do not have specific fieldwork hours identified in the syllabi require teacher candidates to plan, implement and assess developmentally appropriate instructional activities and document the developmental progression of a case study throughout the semester in which the course is taken. For example, the Early Childhood Mathematics: Birth-Grade 2 Implementation and Impact project requires students to develop appropriate math activities for young children. The goal of this assignment is to provide students with an opportunity to use their individual creativity to develop activities as well as to draw upon and synthesize much of what they learned in the course. To support students in understanding how and what children learn from the activities, teacher candidates assess children's learning through observations and interviews. They are also required to provide an evaluation of children's learning and understanding of mathematics based on their observations of children during and after the activity as well as using their clinical interview and anecdotal documentation.

\subsection{Pre-student Teaching}

Pre-student teaching is the experience in a classroom prior to student teaching, including practicum. In the early childhood program, pre-student teaching is taken after the completion of 12 credit hours for graduate student teacher candidates that do not have prior certification. This course has two purposes: To support teacher candidates in examining their own interest in the teaching profession and to make an informed personal decision about teaching as a career choice, and to allow education faculty to learn the teacher candidate's aptitude, motivation and personal suitability for teaching.

\subsection{Student Teaching}

In a study conducted by Lee, Tice, Collins, Brown, Smith, et al., (2012), when compared to their perceptions of preparedness to plan curricula prior to student teaching experiences, teacher candidates perceived themselves to be significantly more prepared after student teaching. With student teaching experiences, teacher candidates reported that they felt better prepared in regard to having acquired knowledge and abilities deemed necessary for successful teaching as set forth by standards for early childhood educators.

Student teaching builds upon previous theoretical and clinical experiences. Student teaching is the point in the early childhood teacher education program in which teacher candidates have the opportunity to experience the complexities of an authentic teaching experience, but still have the support of their seminar instructors, cooperating teachers, and field supervisors. Student teaching experiences expose teacher candidates to settings that include cultural, linguistic, racial and ethnic diversity in families and communities. Student teaching occurs in conjunction with a seminar that is designed to support and enhance the work a student teacher does in the field. The goal of the student teaching experience is for the candidate to be able to transition from theory to practical application in a real world situation. It provides the teacher candidate the opportunity to acquire the knowledge, skills and values of the teaching-learning process where ideas can be implemented and assessed. 
The NAEYC Standards require that early childhood teacher preparation programs assign fieldwork and student teaching experiences in at least two age groups in at least two early education settings. The early childhood program requires teacher candidates to have fieldwork and clinical experiences at 3 age-levels: Prekindergarten (all ages prior to Kindergarten), Kindergarten, and Grades 1 and 2. These experiences are embedded at identified points in the early childhood program and coursework to ensure that teacher candidates have a variety of experiences throughout their program of study.

\section{Data Collection}

Journal writing can facilitate reflection and allow teacher candidates to express feelings regarding their educational experiences. The format of this writing can vary depending on the students' needs and the instructor's goals. Teacher candidates are able to articulate their thoughts through journaling, which can be very beneficial for both their personal and professional growth. As part of the coursework for the student teaching practicum class, the early childhood teacher candidates were required to submit four journal entries throughout the semester.

The topics for the journal entries included stages of teacher development and culturally responsive differentiated instruction. The teacher candidates were also required to review a Teacher Performance Assessment (edTPA) to determine their strengths and needs in regards to completing an assessment portfolio as part of the certification process. For the final journal entry, the teacher candidates were required to reflect on their prior coursework and student teaching experience and how these experiences had influenced and impacted their ideas about teaching in the early childhood field as well as their readiness for becoming professionals in the field. All journal entries had prompts and/or accompanying journal articles to support the teacher candidates in their reflections. The journal entries were the main source of data collection for this study.

\section{Data Analysis}

With journal writing being a form of reflective writing by individuals about their experiences, observations, feelings and ideas, most of the research has been qualitative in nature. As qualitative data analysis is not linear, Seidel's (1998) data analysis process to ascertain trends and themes in the journal entries were used. The foundation of noticing, collecting and thinking about events, objects and people has characteristics that are iterative and progressive, recursive and holographic. This process was used throughout the course of identifying themes and attaching labels and was cyclical during coding.

During the exploratory phase of ascertaining characteristics of the teacher candidates' responses, an a priori approach was used to identify initial themes. The data was initially coded based on a review of the literature and the researchers' experience as a teacher and teacher educator. Planning and differentiated instruction were identified as initial themes because these topics were consistently included in early childhood course syllabi and are an essential component of the teaching process in early childhood education. They are well-established topics in the literature and it was a reasonable assumption that these topics would be addressed in the journal entries.

Although a priori themes were identified in advance, the data was examined inductively allowing the codes to emerge from the empirical data that were outside of my lens. Identifying phrases and words that were repeated in the journals allowed for the objective, transparent representations of facts that enabled further investigation and discovery into the teachers' experiences and perceptions Words that occurred often were seen as being salient in the minds of the teacher candidates. An analysis of word frequencies was done by generating a list of all the recurring words in each of the four journals and then counting the number of times each one occurred. For example, whenever the words lesson, plans, lesson planning, learning segment and planning appeared in the journal entries, it was counted as an occurrence. After using an iterative and recursive process during open coding, four overarching themes emerged: Planning, self-reflection, differentiated and culturally responsive instruction, and assessment.

\section{Findings}

The teacher candidates' reflective journal entries and the themes that emerged, for the most part, aligned with the NAEYC Standards for Early Childhood Professional Preparation Programs. Teacher candidates appeared to recognize that being an early childhood professional means having an understanding of the specialized knowledge required to be effective in early childhood education. They appeared to be aware that providing responsive, supportive curricula, which acknowledges and respects the whole child and family and their cultural backgrounds is an integral aspect of the early childhood profession. The teacher candidates also appeared to recognize that competence in the planning, implementation and assessment of developmentally appropriate activities are essential for effective professional performance.

As a priori themes come from the characteristics of the phenomenon being studied and are consistently supported in the literature, it was not surprising that planning and differentiated instruction materialized as a trend in the teacher 
candidates' responses. Reflection and assessment also emerged as themes. Chart 1 depicts the percentage of teacher candidates that mentioned each theme at least once in each of their four journal entries.

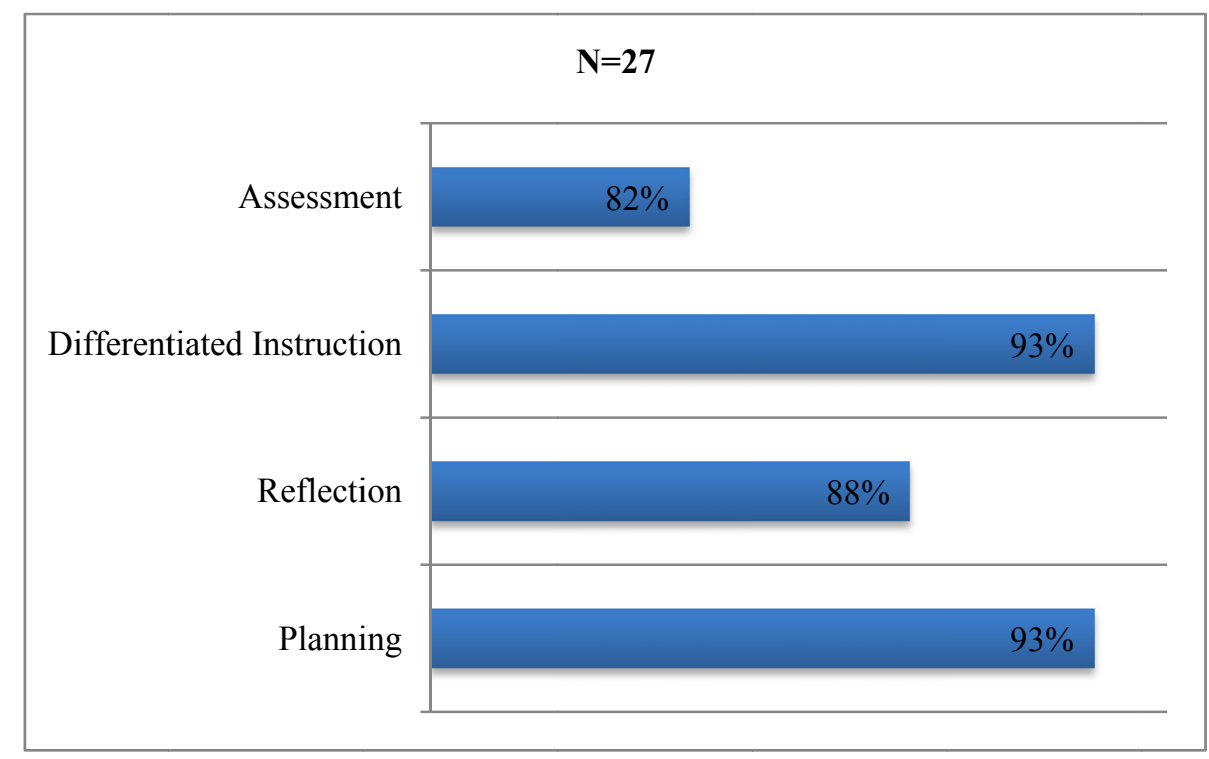

Chart 1. Teacher candidates journal entry themes

\section{Themes}

\subsection{Planning}

The teacher candidates indicated that planning was a critical part of teaching and that their coursework guided them in planning developmentally appropriate curricula that supported all learners. In early childhood education, curriculum planning includes: Goals for children's development and learning; experiences through which they will achieve these goals; what teaching staff and other adults can do to support children in achieving these goals; and the resources needed to support the implementation of the curriculum (National Center on Quality Teaching and Learning (NCQTL), 2012). A teacher candidate stated that, "I feel that teachers are responsible for promoting each child's development by planning lessons and activities that are developmentally appropriate and based on the need of each student." In alignment with the NAEYC Standard 5, the teacher candidates appeared to understand the importance of using the knowledge of individual children to design, implement and evaluate developmentally meaningful and challenging curriculum is a critical component of being a professional in early childhood.

Another teacher candidate stated, "Teachers are responsible for promoting each child's development by planning lessons and activities that are developmentally appropriate and based on the need of each student. Teachers observe, document and assess their students so they may use the information to plan curriculum to promote growth and child development for each child." This reflection aligns with NAEYC Standard 3, which indicates that the teacher candidate is aware that professionalism in early childhood education requires teachers to understand that child observation, documentation, and other forms of assessment are central to the practice of all early childhood professionals.

\subsection{Self-reflection}

Professionalism requires the integration of reflective teaching practice into classroom and instructional routines (Cimer, Cimer, \& Vekli, 2013). Experienced teachers reflect on and adjust their instruction to accommodate the needs of the diverse learners in their classrooms. The degree of reflection is dependent on the level of knowledge and experience the teacher has acquired. Reflective teaching is characterized by an intentional competence that enables teachers to identify and replicate best practices as well as adapt, adjust and refine these practices. Teacher candidates stated that writing about and reflecting on their teaching was a meaningful activity. For example, a candidate stated:

"One last part about becoming an Early Childhood teacher is that we must be reflective of our teaching practices. Reflection plays a key role in teaching because it allows for teachers to self-evaluate our own teaching methods. It lets us learn from our students and it improves how we teach. We learn which lessons work and which have not. This course has taught me to be very reflective of my teaching."

Another teacher candidate stated that, "One of the most important things that I learned through practicum was the importance of self-reflection. Though reflection is something that I've always found theoretically valuable, this was the first time that I 
was able to follow through on doing so on a regular basis. What regular reflection helped me see was not only the areas needing improvement, but also my areas of strength. As I learned, it is just as important to reflect on what is going well so that I can repeat those things in the future and work off of positive qualities instead of focusing on the negative."

\subsection{Differentiated and Culturally Responsive Instruction}

De Jesus (2012) identifies the main advantages of differentiation as meeting the needs of diverse students with a variety of learning styles, accommodating students with learning disabilities or other types of disabilities, facilitating language learning to students from different cultures such as English Language Learners, and stimulating creativity and helping students understand ideas at higher levels of thinking (p.7). Differentiated instruction recognizes students' varying background knowledge, readiness, language, preferences in learning and interests and assists teachers in knowing how to discern instruction given these various learning areas. Culturally responsive practices are specific educational practices, instructional strategies, team processes and curricula content that have been established by research to increase the achievement of culturally diverse students. Teacher candidates identified differentiated and culturally responsive instruction as strategies that will support them in their classrooms. NAEYC Standard 4 states that candidates know the cultural practices and contexts of the young children they teach, and they adapt practices as they continue to develop cultural competence, culturally relevant knowledge and skills. A teacher candidate was aware of this and wrote in the journal:

"As a bilingual Teacher who's students majority are ELL, I totally agree that children learn better when there culture, language, and background knowledge is accepted in the classroom and embraced in the curriculum lessons. Therefore one of the pedagogies that I will like to practice when I have my own classroom is the culturally responsive pedagogy."

\subsection{Assessing Children's Knowledge Acquisition}

The most effective programs use ongoing assessment for teachers to assess whether or not young children were learning and to make adjustments if expectations were not being met (Barnett, 2008). Assessment of individual children's development and learning is essential for planning and implementing appropriate curriculum. Assessment of young children's progress and achievements is ongoing, strategic, and purposeful (Mayesky, 2014). Drawing on children's background knowledge and experiences can be an effective way to assess their prior knowledge. Teacher candidates reported that writing lesson plans that required them to identify the prior knowledge that was necessary for successful implementation of the activities was useful.

"My three learning segments also helped me to understand how children use prior knowledge and memories to understand each new topic presented to them."

In alignment with NAEYC Standard 4, students prepared in early childhood degree programs understand that child observation, documentation, and other forms of assessment are central to the practice of all early childhood professionals, a teacher candidate understood the goals, benefits, and uses of assessment:

"Another aspect of becoming an Early Childhood teacher and professional is developing and implementing assessments. Working with younger children we have the task of not only assessing their knowledge but also their developmental progression. Our lessons have to be planned specifically to meet the needs of all our students in order to help them developmentally. The assessment article was helpful in that it explained how assessments need to guide our instructions. I agree with this because it gives teachers a guide on what lessons to incorporate in the classroom. it also provides a way for the teacher to reflect on his/her lessons and modify anything that did not work."

\section{Meeting the goals of the NAEYC Standards}

In aligning the key elements of Standard 6: Growing as a Professional in the NAEYC Standards with the teacher candidates journal entries, the themes that emerged met the goals of 3 out of the 7 elements:

1. 6c: Using professional resources, inquiry skills and research methods to engage in continuous, collaborative learning and investigation relevant to practice and professional role.

2. 6d: Integrating knowledgeable, reflective, and critical perspectives on early education based upon mastery of relevant theory and research

Although mastery is not an expectation at the novice level, the early childhood teacher candidates indicated that reading journal and research articles and using the applicable information would support them as they entered the field.

"My coursework has also helped me see that teaching is a huge learning process and will not become a fully-honed craft for a long time. It is essential to continue growing as a teacher by also growing as a learner. There will never be a time where you cannot find something to improve upon. Doing consistent research, attending professional development and seeking new mentors and models are just some ways that I can continue to develop as a teacher even after school ends." 
3. 6e: Engaging in informed advocacy for children and the profession, skillfully articulating and advocating for sound professional practices and public policies.

"Children's advocacy was an important topic we covered in class. I found this to be the most relevant as it pertains to the health and safety of my students. Because of our busy schedule this semester, I think some of us got caught up in the course work but what truly draws us to this field the children's advocacy. Before this practicum, I had never thought of contacting congressmen or government officials on behalf of students. It seemed far fetched to me. However, after reading about the subject I have realized that in my future as a teacher I want to be the best advocate I can be. I want to lobby, write letters to congressmen and make sure that I am advocating for young children."

The reflective journal entries partially met the goals of 2 of the elements in the NAEYC Standards:

6a: Demonstrating professional identification with and leadership skills in the early childhood field to think strategically, build consensus, create change, effectively collaborate with and mentor others, and have a positive influence on outcomes for children, families and the profession.

Even though none of the reflections identified leadership opportunities or skills in their journal entries, a teacher candidate identified how having a supportive director and collaborative colleagues helped build her confidence in teaching.

"Another important thing that I learned through my coursework was the value of teamwork and collaboration. After deciding to leave my first job in September with an unsupportive director and team members, my confidence was very low and I felt very uneasy and defeated going into a new job. However, I found that being around a very supportive director and colleagues has allowed me to grow as a teacher and to see that I do have some strengths in teaching. Having people to help you learn and grow is essential in the teaching field, not only for professional development, but also for the children being taught. If the teachers have a harmonious relationship and the best interest of the children at heart, it makes the learning environment more comfortable and productive. Also, being able to have some confidence in teaching goes a long way, as the children pick up on your feelings day to day."

2. 6f: Demonstrating a high level of oral, written and technological communication skills with specialization for specific professional role(s) emphasized in the program.

Teachers must be able to express themselves both verbally and in writing in order to report student progress to parents. Although the early childhood teacher candidates recognized that effective communication was essential in communicating with colleagues, only one teacher candidate indicated how support and guidance of the coach assisted her in dealing with difficult situations involving administration and parents.

"Throughout the program, I also received guidance and was coached through many difficult situations regarding parent and administrator communication. As a new teacher, it is sometimes difficult to understand when to extend communication and when not to, and the ability to confer with my colleagues and professors in challenging situations was very helpful."

The reflective journal entries did not meet the goals of 1 of the elements in the NAEYC Standards: 6b: In-depth understanding and thoughtful application of NAEYC Code of Ethical Conduct and other professional guidelines relevant to their professional role. Chart 2 depicts the percentage of students who had statements in their journals that were related to themes and ideas in NAEYC Professional Standard 6: Growing as a Professional.

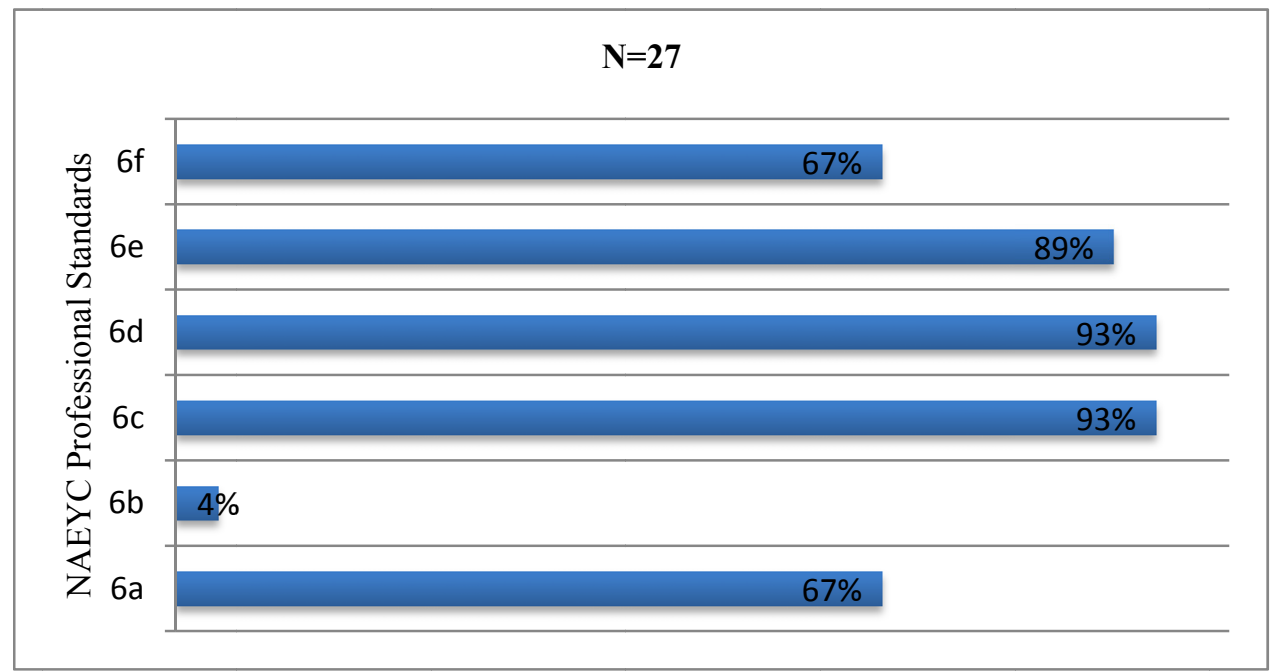

Chart 2. Teacher candidates' journal entries alignment with NAEYC Professional Standard 6 
The NAEYC Code of Ethical Conduct (Code) offers "guidelines for responsible behavior and sets forth a common basis for resolving the principal ethical dilemmas encountered in early childhood care and education" (NAEYC, 2011, p.1). The ideals and principles in the Code present a shared framework of professional responsibility that affirms the commitment to the core values of the early childhood field. Although an early childhood teacher candidate identified professional ethics in regards to teaching practices, there was no discussion in the journal reflections of how the Code guidelines affected teacher candidates' preparation to become a professional in the field.

"Teachers must be professionals in their practice following the professional ethics and standards set forth in the early childhood education field; and they must consistently improve their own skills and abilities to become proficient in the early childhood education field."

\section{Limitations}

The small sample size of early childhood teacher candidates limited the generalizability of this inquiry in several ways. The teacher candidates that participated in this study were part of a rigorous accelerated program, which, as indicated in their journal entries, was demanding and stressful. These teacher candidates did not follow the suggested pacing of course work that is encouraged for the typical teacher candidate in the early childhood program. Although the teacher candidates had mentors and coaches throughout the program, they did not receive regular advisement from the early childhood program faculty during their course of study. In addition, the small sample size was from a specialized program, which excluded the larger graduate population. Although the results of this study cannot be generalized to all teacher candidates, this study can support early childhood programs in aligning their program of study with the NAEYC Standards for Initial \& Advanced Early Childhood Professional Preparation Programs to prepare teacher candidates to become professionals in the field.

\section{Discussion}

The purpose of this qualitative study was to examine teacher candidates' perceptions about their preparation and readiness to become professionals in the field of early childhood education. The results of this inquiry determined that the early childhood teacher candidates felt that the teacher preparation program provided them with a foundation in understanding young children's characteristics and needs, planning appropriate and differentiated environments that are culturally responsive to the needs of all children and being reflective. Teacher candidates also indicated that being a reflective practitioner that understands the goals, benefits and uses of assessment in early childhood is a critical part of becoming a professional in the field.

All of the courses and syllabi in the early childhood teacher education program are aligned with the NAEYC Standards for Early Childhood Professional Preparation Programs. Implications from this inquiry suggest that the early childhood program should ensure the fidelity to the NAEYC Standards by aligning assignments that incorporate the language and expectations of the Standards, especially in regards to element $6 \mathrm{~b}$. Course leaders and curriculum developers in the early childhood teacher preparation program must confirm that the goals and objectives of the NAEYC Standards are clearly outlined and articulated in the syllabus and follow-up observations of faculty during instruction meets these expectations.

"Professionalism is an ongoing process that requires time and commitment to deepen one's knowledge of the field, develop competence in professional performance, and to demonstrate commitment to ethical standards" (Castle, 2009, p. 9). While a degree in any field demonstrates increased professional knowledge, degrees, coursework and diverse student teaching experiences that are directly related to the field of early childhood and aligned with Early Learning Guidelines demonstrate the truly specialized knowledge required to most effectively support young children's growth and learning. This specialized knowledge also supports early childhood professionals in guiding families to understand young children's development. In addition, an early childhood professional has the characteristics, knowledge and skills necessary to teach and conduct programs so that all children have the ability to learn.

Training to be an early childhood professional is continuous and evolves around the intentional reflections about practices, responsibilities, strengths, challenges, as well as hopes and dreams for working with young children (Caulfield, 1997; NAEYC, 2012).

Professionalism in early childhood requires knowledge and competency in all areas of child growth and development, educational strategies and skills to develop, implement and manage high-quality programs. Early childhood professionals must make a commitment to the standards of the profession, its code of ethics, and the profession overall (Castle, 2009).

This study demonstrated that the teacher candidates had high-standards and expectations for themselves and the young children they worked with. As they prepared to be professionals in the field, they saw the value in their coursework, corresponding fieldwork and student teaching experiences. The journal entries that were submitted also indicated that 
the teacher candidates were self-aware, intuitive and perceptive about the knowledge and skills that is required to be effective in the early childhood profession. The analysis from this study indicated that the teacher candidates' perceptions about their education and preparation to be a professional in the early childhood field appears to rely on reflective teaching practices and an understanding of all children's unique academic, emotional and cultural differences.

Teachers of young children work hard to be professional and to be viewed by others as professionals (Harte, 2011). Professionalism is not an end in itself, but is an ongoing effort (Caulfield, 1997). The commitment to the practice of professionalism in early childhood education begins with utilizing the NAEYC Standards for Initial \& Advanced Early Childhood Professional Preparation Programs in teacher preparation programs. With experience and continuous professional development, early childhood teacher candidates have the opportunity to apply the knowledge gained through formal education and training to increase their skills as professionals.

"Based on the early childhood coursework I have learned that teaching is not easy. There are many, many aspects to teaching. In addition to knowledge, multitasking and organization skills there are professional standards that must be met" (Early Childhood Teacher Candidate, 2015).

\section{References}

Bredekamp, S., \& Goffin, S. G. (2012). Making the case: Why credentialing and certification matter. In R.C. Pianta (Ed.), Handbook of early childhood education (pp 584-604) New York: Guilford Press.

Brock, A. (2006). Dimensions of early years professionalism: Attitudes versus competences. Paper from the Association for the Professional Development of Early Years Educators (TACTYC). Available online at www. tactyc. org. uk/pdfs/Reflection-brock. pdf

Castle, K. (2009). What do early childhood professionals do? Dimensions of Early Childhood, 37(3), 4-10.

Caulfield, R. (1997). Professionalism in early care and education, Early Childhood Education Journal, 24(4), 261-263. https://doi.org/10.1007/BF02354843

Cimer, A., Cimer, S. O., \& Vekli, G. S. (2013). How does reflection help teachers to become effective teachers. International J. Educational Research, 1(4), 2306-7063.

De Jesus, O. N. (2012). Differentiated instruction: Can differentiated instruction provide success for all learners? National Teacher Education Journal, 5(3), 5-11.

Division for Early Childhood (DEC) of the Council for Exceptional Children. (2009). Code of ethics. Retrieved on March 19, 2012 from: http://www.dec-sped.org/position-statements

Dudiak, M., Dembroski, C., Kelly, K., \& McNair, R. (2015). Blurred lines: Clearing the fog of effective clinical practice beyond traditional semester learning. Retrieved on June 22, 2016 from: http://napds.org/wp-content/uploads/2015/07/PDS-Partners-Volume-11-Issue-1-Summer-2015.pdf

Gordon, A., \& Browne, K. W. (2015). California edition beginning essentials in early childhood education. Boston, MA: Cengage Learning.

Harte, H. (2011). E-professionalism for early care and education providers. Dimensions of Early Childhood, 39(3), $3-10$.

Lee, J., Tice, K., Collins, D., Brown, A., Smith, C., \& Fox, J. (2012). Assessing student teaching experiences: Teacher candidates' perceptions of preparedness. Educational Research Quarterly, 36(2), 3-20.

Mayesky, M. (2014). Creative activities and curriculum for young children. Boston, MA: Cengage Learning.

National Association for the Education of Young Children (NAEYC). (2005). Code of ethical conduct and statement of commitment: A position paper. Retrieved on May3, 2014 from: https://www.naeyc.org/files/naeyc/file/positions/PSETH05.pdf

National Association for the Education of Young Children (NAEYC). (2012). 2010 Standards for initial \& advanced early childhood professional preparation programs. Washington, DC: Author. https://www.naeyc.org/caep/files/caep/NAEYC\%20Initial\%20and\%20Advanced\%20Standards\%2010_2012.pdf

National Association for the Education of Young Children. (2012). Code of ethical conduct and statement of commitment. Washington, DC: Author. Retrieved on March 10, 2014 from: https://www.naeyc.org/caep/files/caep/NAEYC Initial and Advanced Standards 10_2012.pdf

National Association for the Education of Young Children. (n.d.). Who are early childhood professionals? Washington, DC. 
National Center on Quality Teaching and Learning (NCQTL). (2012). Choosing a preschool curriculum. . Retrieved on April 16, 2015 from: http://eclkc.ohs.acf.hhs.gov/hslc/tta-system/teaching/docs/preschool-curriculum.pdf

Professional Standards Council (PSC). (2015). 21 years of regulatory innovation through professional standards. Retrieved on March 15, 2016 from:

http://www.psc.gov.au/sites/default/files/21\%20years\%20of\%20regulatory\%20innovation\%20through\%20professi onal\%20standards.pdf

Seidel, J. (1998). Qualitative data analysis: Ethnograph 5.0. Colorado Springs, CO: Qualis Research.

Sheridan, S. M., Edwards, C. P., Marvin, C. A., \& Knoche, L. L. (2009). Professional development in early childhood programs: Process issues and research needs. Early Education and Development, 20(3), 377-401. https://doi.org/10.1080/10409280802582795

Tigistu, K. (2013). Professionalism in early childhood education and care in Ethiopia: what are we talking about? Childhood Education, 89(3), 152-158. https://doi.org/10.1080/00094056.2013.792641

Watts, J. (2009). Professionalism in early childhood education (unpublished masters thesis). Humboldt State University: Arcata, CA.

\section{Copyrights}

Copyright for this article is retained by the author(s), with first publication rights granted to the journal.

This is an open-access article distributed under the terms and conditions of the Creative Commons Attribution license which permits unrestricted use, distribution, and reproduction in any medium, provided the original work is properly cited. 